\title{
ANALISIS KEMAMPUAN BERPIKIR KREATIF DALAM MENULIS KARANGAN NARASI SISWA KELAS V SDN PONDOK BAHAR 5 KOTA TANGERANG
}

\section{ANALYZE CRETIVE THINKING ABILITY IN WRITING NARRATION OF STUDENTS CLASS V SDN PONDOK BAHAR 5 KOTA TANGERANG}

\author{
Puji Rahayu $^{1}$, Enawar ${ }^{2}$, Dilla Fadhillah ${ }^{3}$, Sumiyani ${ }^{4}$ \\ Universitas Muhammadiyah Tangerang, Kota Tangerang \\ 1․ㅏahayu699@gmail.com, ${ }^{2}$ enawar.abah@gmail.com, ${ }^{3}$ dillafadhillah89@gmail.com, \\ ${ }^{4}$ sumiyaninitura@gmail.com
}

\begin{abstract}
ABSTRAK
Fokus penelitian ini adalah untuk menganalisis kemampuan berpikir kreatif dalam menulis karangan narasi siswa kelas V SDN Pondok Bahar 5 Kota Tangerang. Penelitian ini dilaksanakan dengan tujuan untuk mengetahui bentuk kemampuan berpikir kreatif dalam menulis karangan narasi siswa kelas V SDN Pondok Bahar 5 Kota Tangerang. Penelitian ini menggunakan pendekatan deskriptif kualitatif, dengan mendeskripsikan hasil karangan narasi siswa kelas V SDN Pondok Bahar 5 Kota Tangerang dalam kemampuan berpikir kreatif menulis karangan narasi tanpa direkayasa. Sumber data dalam penelitian ini adalah wali kelas V dan siswa kelas V. Pengumpulan data dilakukan dengan teknik tes, wawancara, observasi dan dokumentasi. Hasil penelitian ini menunjukkan bahwa adanya kesalahan yang dilakukan siswa dalam kemampuan berpikir kreatif menulis karangan narasi. Kesalahan tersebut yaitu ide dan gagasannya tidak diperluas serta kalimat yang dituliskan masih kurang tepat.
\end{abstract}

Kata Kunci: Kemampuan, Berpikir Kreatif, Karangan Narasi.

\section{ABSTRACT}

This research is focussed to analyze cretive thinking ability in writing narration of students class V SDN Pondok Bahar 5 Kota Tangerang. The aim of this research to know the form of creative thinking ability in writing narration of students class V SDN Pondok Bahar 5 Kota Tangerang. This research used qualitative descriptive approach, by describe the result of narration student class V SDN Pondok Bahar 5 Kota Tangerang in creative thinking ability writing narration without manipulation. The resource in this research are home room teacher and studentclass $V$. The collecting data did by technique test, interview, observation, and documentation. The result of the research show that there was an eror which student done on creative thinking ability in writing narration. The eror were idea, the concept not expanded and write the sentence still not appropriate.

Keyword: ability, creative thinking, narration.

\section{PENDAHULUAN}

Pendidikan merupakan suatu upaya dalam mengembangkan kemampuan yang ada di dalam diri manusia dengan cara mengarahkan dan membimbingnya kearah yang lebih baik. Pengembangan kemampuan yang dimiliki manusia sangatlah penting, sehingga manusia mampu bertahan hidup dengan kemampuan yang dimilikinya. Dengan pendidikan akan tercipta manusia yang berpotensi cerdas, terampil, kreatif, berbudi pekerti luhur dan memiliki ide 
cemerlang sebagai bekal untuk memperoleh masa depan yang lebih baik, yang semuanya itu berdasarkan atas ketakwaan kepada Tuhan Yang Maha Esa.

Dapat dikatakan bahwa setiap Negara atau Bangsa selalu menyelenggarakan pendidikan demi cita-cita Nasional Bangsa. Sehubungan dengan hal tersebut, di dalam Undang-Undang Republik Indonesia Nomor 20 Tahun 2003 Pasal 3 Ayat 1 yang berbunyi: "Pendidikan nasional berfungsi mengembangkan kemampuan dan membentuk watak serta peradaban bangsa yang bermartabat dalam rangka mencerdaskan kehidupan bangsa, bertujuan untuk berkembangnya potensi peserta didik agar menjadi manusia yang beriman dan bertakwa kepada Tuhan Yang Maha Esa, berakhlak mulia, sehat, berilmu, cakap, kreatif, mandiri, dan menjadi warga Negara yang demokratis serta bertanggung jawab"

Seiring dengan tuntunan zaman, dunia pendidikan juga perlu di kembangkan, dalam hal ini misalnya dalam kegiatan pembelajaran di dalam kelas perlu pengembangan dalam sebuah pembelajaran yang digunakan guru dalam proses belajar mengajar dikelas. Sehingga pembelajaran tidak hanya diartikan dengan mentrasfer ilmu dari guru untuk muridnya. Dalam pendidikan terdapat beberapa jalur pendidikan yang terdiri dari pendidikan formal, nonformal, dan informal. Pada jenjang pendidikan formal terdiri dari sekolah dasar sampai perguruan tinggi.

Pendidikan Sekolah Dasar merupakan pendidikan anak yang berusia antara 7 sampai dengan 13 tahun yang di kembangkan sesuai dengan satuan pendidikan yang diberikan kepada siswa dengan sejumlah materi atau mata pelajaran yang harus dikuasai oleh siswa. Sehingga mengembangkan potensi dirinya untuk memiliki kekuatan spiritual keagamaan, pengendalian diri, kepribadian, kecerdasan, akhlak mulia, serta keterampilan yang diperlukan dirinya dan masyarakat, dalam berbangsa dan bernegara. Dalam Sekolah Dasar sudah memakai kurikulum 2013, kurikulum ini merupakan kurikulum tetap diterapkan oleh pemerintah untuk menggantikan Kurikulum-2006. Sehingga di kurikulum 2013 ada beberapa mata pelajaran yang bersangkutan dengan kurikulum yaitu: PPKN, Bahasa Indonesia, IPA, IPS, Matematika, Pendidikan Jasmani Olahraga dan kesehatan, dan Seni Budaya. Salah satunya adalah Mata Pelajaran Indonesia.

Pengajaran Bahasa Indonesia secara formal sudah dimulai sejak sekolah dasar. Salah satunya adalah bahwa Bahasa Indonesia berfungsi sebagai alat komunikasi yang tentu saja dapat mempengaruhi perkembangan peserta didik dalam hal pengetahuan dan keterampilan berbahasa, sehingga peserta didik dapat dengan mudah berinteraksi dan beradaptasi dengan lingkungan sosialnya. Selain itu fungsi berbahasa dalam hal pendidikan, peserta didik dapat memahami tentang pengenalan dan keterampilan dalam berbahasa sehingga akan membantu prosesnya dalam belajar agar mendapatkan hasil yang optimal. Keterampilan dalam bahasa Indonesia dapat dipelajari oleh siswa secara bertahap, dimulai dari keterampilan yang paling mudah dan akan terus meningkat sampai keterampilan yang paling susah. Pembelajaran keterampilan dalam bahasa Indonesia memerlukan berbagai upaya yang harus terus ditingkatkan agar hasil yang dicapai siswa sesuai dengan yang diharapakan.

Peningkatan keterampilan berbahasa Indonesia selalu berkaitan dengan berbagai kebutuhan yang sesuai dengan situasi dan 


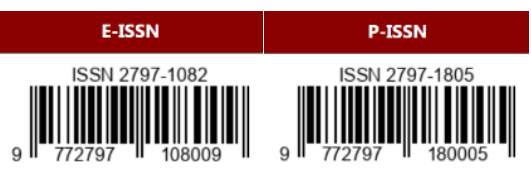

kondisi siswa, baik kebutuhan lisan maupun tulisan. Terampil berbahasa berarti siswa dapat terampil dalam beberapa aspek yang ada dalam pembelajaran bahasa Indonesia yaitu, keterampilan menyimak (listening skill), keterampilan berbicara (speaking skill), keterampilan membaca (reading skill), dan keterampilan menulis (writing skill). Keterampilan menulis merupakan salah satu materi dan bidang aktivitas yang memegang peran sangat penting yang dapat dilakukan siswa dalam pembelajaran bahasa Indonesia di Sekolah Dasar (SD). Menulis merupakan bagian dari empat keterampilan yang ada dalam pembelajaran bahasa Indonesia yang tentu saja harus dikuasai dengan baik oleh siswa.

Menulis juga merupakan keterampilan yang sulit dari empat keterampilan berbahasa yang lainnya, karena dalam menulis memerlukan keterlibatan dalam proses berpikir kreatif. Hal tersebut sesuai dengan Standar Kompetensi (SK), yaitu “ Mengungkapkan pikiran, perasaan, informasi, dan pengalaman secara tertulis dalam bentuk karangan, surat undangan dan dialog khusus " dan Kompetensi Dasar yang berbunyi “ Menulis karangan berdasarkan pengalaman dengan mempertahankan pilihan kata dan penggunaan ejaan ”, dalam Kurikulum 2013. Keterampilan menulis karangan dalam berpikir kreatif kenyataanya siswa masih belum sesuai dengan harapan. Pelajaran mengarang sebagai salah satu aspek dalam pengajaran Bahasa Indonesia yang kurang ditangani secara sungguh-sungguh. Akibatnya, kemampuan-kemampuan berbahasa Indonesia parasiswa kurang memadai. Maka dari itu berpikir kreatif dalam menulis karangan sangat dibutuhkan agar siswa dikatakan terampil dalam menulis, maka diperlukan ide-ide yang bisa dituangkan dalam sebuah bentuk karangan.

Berdasarkan hasil wawancara awal dengan guru wali kelas saat observasi tanggal 20 Februari 2021 kelas V SDN Pondok Bahar 5 Kota Tangerang mengenai mata pelajaran Bahasa Indonesia ditemukan kendala-kendala yang terdapat dalam proses pembelajaran Bahasa Indonesia yang kurang disenangi atau diminati siswa adalah menulis. Guru kelas V mengungkapkan masih banyak siswa yang mengalami kesulitan dalam menulis karangan narasi masih sangat rendah. Penilaian dilandasi oleh hal-hal seperti: siswa sering merasa jenuh jika disuruh mengarang, karangan narasi yang dibuat masih agak singkat, ide atau gagasan siswa masih kurang berkembang, kosakata yang digunakan siswa masih sederhana, serta penggunaan kalimat dan bentuk tulisan narasi masih kurang terarah. Siswa masih banyak yang kurang memperhatikan guru yang sedang mengajar, sehingga jika di tugaskan untuk mengerjakan tugas siswa masih kebingungan dan pada saat ulangan nilainya pun di bawah KKM yaitu dengan nilai 70 .

Alasan peneliti mengangkat permasalahan yang terjadi di SDN Pondok Bahar 5 Kota Tangerang karena, pada mata pelajaran Bahasa Indonesia yang kurang disenangi atau diminati siswa dalam menulis. Hal ini menyebabkan siswa kurang termotivasi dalam mengikuti pelajaran Bahasa Indonesia. Sedangkan kemampuan menulis karangan sangat penting dikuasai siswa karena dengan menulis karangan siswa dapat berpikir kreatif, dapat berkomunikasi dengan pembaca dan mampu memperdalam daya tangkap siswa. Banyak hal yang harus diperhatikan dalam kegiatan menulis meliputi pengunaan ejaan, pemilihan kata, penyusunan kalimat, dan pembuatan paragraf. 
Dalam proses pembelajaran menulis karangan narasi, telah ditemukan sejumlah kesalahan. Kesalahan yang sering muncul pada karangan siswa, terletak pada ide dan gagasan siswa yang kurang berkembang, kosakata yang digunakan siswa masih kurang tepat, penggunaan kalimat dan bentuk tulisan siswa masih kurang tepat dan ketika siswa membuat karangan masih agak singkat. Maka dari itu, menulis narasi membutuhkan sebuah pemikiran yang mendalam karena apa yang kita tulis merupakan ide-ide yang kita pikirkan. Dalam menulis karangan narasi siswa dituntut untuk memperhatikan ciri-ciri dari paragraf narasi itu sendiri. Disamping itu siswa juga perlu mengembangkan ide-ide yang kreatif, tidak hanya sekedar mengarang. Oleh karena itu maka siswa membutuhkan pemikiran-pemikiran yang mendalam dengan mengembangkan kemapuan berfikir kreatif untuk menuangkan ide-ide yang cemerlang. Berdasarkan kondisi yang terjadi, maka penulis sangat tertarik untuk meneliti masalah yang berjudul "ANALISIS KEMAMPUAN

BERPIKIR KREATIF DALAM
MENULIS KARANGAN NARASI SISWA KELAS V SDN PONDOK BAHAR 5 KOTA TANGERANG"

\section{METODE PENELITIAN}

Penelitian ini menggunakan pendekatan penelitian kualitatif dengan jenis metode penelitian deskriptif kualitatif. Hal ini dilakukan agar peneliti dapat mendeskripsikan secara jelas dan rinci serta mendapat data yang mendalam tentang, "Analisis Kemampuan Berpikir Kreatif Dalam Menulis Karangan Narasi Kelas V SDN Pondok Bahar 5 Kota Tangerang”. Hal yang sangat diutamakan dalam penelitian kualitatif yaitu dapat mengungkapkan suatu data dan informasi yang dapat ditarik makna dan konsepnya. Sejalan dengan pendapat Mawardi 2019, yang mengungkapkan bahwa: "Penelitian kualitatif adalah penelitian yang bertujuan untuk mendapatkan pemahaman yang mendalam tentang masalah-masalah manusia dan social, bukan mendeskripsikan bagian permukaan dari suatu realitas sebagaimana dilakukan penelitian kuantitatif dengan positivismenya" (h.25).

Penelitian ini dilakukan pada objek yang alamiah, objek yang dapat berkembang apa adanya, tidak dimanipulasi oleh peneliti, dan kehadiran peneliti tidak mempengaruhi dinamika pada objek tersebut. Untuk dapat menjadi sebuah instrument, maka peneliti harus memiliki bekal teori dan wawasan yang luas sehingga peneliti mampu bertanya, menganalisis, memotret, dan mengkonstruksi situasi social yang diteliti menjadi lebih jelas dan bermakna. Tujuan dari penelitian ini yaitu untuk mengetahui kemampuan berpikir kreatif dalam menulis karangan narasi siswa kelas V SDN Pondok Bahar 5 Kota Tangerang. Data dalam penelitian ini diperoleh dengan menggunakan instrument penelitian berupa tes, wawancara, observasi, dan dokumentasi.

\section{HASIL DAN PEMBAHASAN}

Hasil penelitian yang akan disajikan adalah berupa kemampuan berpikir kreatif dalam menulis karangan narasi siswa kelas $\mathrm{V}$ SDN Pondok Bahar 5 Kota Tangerang. Data yang terkumpul dalam penelitian berpikir kreatif dalam menulis karangan narasi ini sebanyak 25 karangan siswa. Hasil karangan tersebut di identifikasi berdasarkan jenis kemampuannya. Jenis kemampuan berpikir kreatif tersebut dibatasi pada empat kemampuan, yaitu Kelancaran (fluency), Keluwesan (flexibility), Originalitas 
(originality), Elaborasi (elaboration) keempat kemampuan tersebut dirinci berdasarkan jenis kemampuan.

Kemampuan berpikir kreatif dalam karangan narasi siswa kelas V SDN Pondok Bahar 5 Kota Tangerang pada 4 aspek kemampuan yaitu kelancaran (Fluency) 56\%, keluwesan (Flexibility) 65\%, Originalitas (Originality) 63\%, dan Elaborasi (Elaboration) $45 \%$. Yang dinilai dari 25 siswa terdapat 6 siswa yang belum memenuhi aspek keterampilan berpikir kreatif.

Setelah dilakukan penelitian kemampuan berpikir kreatif dalam menulis karangan narasi, maka dapat disimpulkan bahwa siswa kelas V SDN Pondok Bahar 5 Kota Tangerang masih belum sepenuhnya memahami bagaimana menulis karangan narasi dengan berpikir kreatif yang benar. Hal ini dapat dilihat dari banyaknya jumlah kemampuan berpikir kreatif dalam menulis karangan narasi dari setiap karangan yang dibuat oleh siswa.

\section{KESIMPULAN}

Berdasarkan hasil penelitian dan pembahasan mengenai Analisis Kemampuan Berpikir Kreatif Dalam Menulis Karangan Narasi Pada pembelajaran Bahasa Indonesia Siswa Kelas V SDN Pondok Bahar 5 Kota Tangerang. Dapat disimpulkan bahwa berpikir kreatif adalah kemampuan menggunakan akal budi untuk menimbang dan memutuskan sesuatu hal agar terciptahal baru atau memiliki nilai kebaharuan dengan cara yang berbeda (Sililahi dkk., 2020).

Kemampuan berpikir kreatif dalam menulis karangan narasi pada siswa kelas V SDN Pondok Bahar 5 Kota Tangerang menunjukkan bahwa peserta didik dalam menulis karangan narasi belum mampu mengeluarkan ide dan gagasannya yang benar sebanyak mungkin secara jelas. Hal ini menunjukkan bahwa kemampuan berpikir kreatif dalam menulis karangan narasi siswa masih rendah dan menyebabkan hanya beberapa peserta didik yang mampu dalam kemampuan berpikir kreatif menulis karangan narasi.

Berdasarkan kesimpulan yang telah diuraikan tentang Analisis Kemampuan Berpikir Kreatif Dalam Menulis Karangan Narasi Siswa Kelas V SDN Pondok Bahar 5 Kota Tangerang maka peneliti memiliki beberapa saran untuk sampaikan ke beberapa pihak yaitu:

1. Bagi institusi

Bagi institusi diharapkan dapat dijadikan bahan referensi tentang kemampuan berpikir kreatif dalam menulis karangan narasi siswa dan menambah wawasan peneliti sebagai bekal untuk masa yang akan mendatang.

2. Bagi Sekolah

Peneliti harap kepada pihak sekolah seharusnya ikut bekerjasama dengan guru dan memberikan solusi untuk membantu kemampuan berpikir kreatif dalam menulis karangan narasi siswa

3. Bagi guru

Kemampuan berpikir kreatif dalam menulis karangan narasi kelas V SDN Pondok bahar 5 Kota Tangerang masih perlu ditingkatkan. Peneliti menyarankan bagi guru untuk memperbanyak interaksi dengan siswa ketika proses pembelajaran berlangsung untuk merangsang keingintahuan siswa serta melatih kemampuan berpikir kreatif siswa dalam menulis karangan narasi serta guru juga harus senantiasa memberikan motivasi kepada siswa agar siswa lebih bersemangat dalam bertanya dan 
memberikan pendapatnya ketika proses pembelajaran berlangsung.

4. Bagi Peneliti

Bagi peneliti selanjutnya disarankan untuk tidak meremehkan tentang kemampuan berpikir kreatif dalam menulis karangan narasi. Karena kemampuan menulis merupakan kemampuan yang sangat penting. Diharapkan peneliti selanjutnya untuk melanjutkan penelitian tentang kemampuan berpikir kreatif dalam menulis karangan narasi siswa agar kemampuannya bisa terus meningkat.

5. Bagi siswa

Kemampuan berpikir kreatif dalam menulis karangan narasi siswa kelas $\mathrm{V}$ SDN Pondok Bahar 5 Kota Tangerang sudah cukup baik. Siswa diharapkan secara sungguh-sunggh berpartisipasi aktif dalam mengikuti pembelajaran, sehingga pengetahuan yang diperoleh benar-benar dipahami dan melekat dalam ingatannya serta pembelajaran akan lebih bermakna. Serta siswa diharapkan memperbanyak latihan menulis dirumah dengan membiasakan menulis serta melakukan kegiatan menulis karangan untuk meningkatkan kemampuan menulis karangan siswa.

\section{DAFTAR PUSTAKA}

Andini Putri, K. ., Enawar, E., Fadhillah, D. ., \& Sumiyani, S. (2021). Analisis Keterampilan Berbicara Pada Pembelajaran Bahasa Indonesia Siswa Kelas V SD Negeri Kutabumi 1 Kabupaten Tangerang. Berajah Journal, 1(3), 147-153. https://doi.org/10.47353/bj.v1i3.35

Annisa. (2018). Kemampuan Menulis Karangan Narasi Peserta Didik Kelas VI Di Mis Nurul Jihad Pintulung
Kelurahan Tassilu Kecamatan Sinjai Barat Kabupaten Sinjai. Skripsi. Makassar: Universitas Islam Negeri Alauddin Makassar.

Dalman. (2020). Keterampilan Menulis. Jakarta: PT Raja Grafindo Persada.

Edi, Sarwo, Rosi, Fandi. (2016). Teori

wawancara Psikodiagnostik.

Yogyakarta: PT Leutika Nouvalitera.

Fadhillah, Dilla, dkk. (2018). Pembelajaran

Bahasa Indonesia Kelas Rendah. Yogyakarta: Samudra Biru.

Fadhillah, Dilla, dkk. (2019). Pembelajaran Bahasa Indonesia Kelas Tinggi. Yogyakarta: Samudra Biru.

Harisuddin, Iqbal, Muhammad. (2019). Secuil Esensi Berpikir Kreatif \& Motivasi Belajar Siswa. Bandung: PT Panca Terra Firma.

Hidayat, Ahmad. (2021). Menulis Narasi

Kratif Dengan Model Project Based

Lerning Dan Musik Instrumental.

Yogyakarta: Deepublish.

Isma Imelda, M. ., Sari Ramdhani , I. .,

Enawar, E., \& Sumiyani, S. (2021).

Analisis Keterampilan Berbicara Pada

Pembelajaran Bahasa Indonesia Siswa

Kelas IV SDN Kampung Melayu 4

Kabupaten Tangerang. Berajah Journal, 1(3), 180-186.

https://doi.org/10.47353/bj.v1i3.41

Ismail, ilyas, muhammad. (2020). Evaluasi

Pembelajaran, Konsep Dasar, Prinsip,

Teknik, dan Prosedur. Depok: PT Raja

Grafindo Persada.

Lie, Anita, dkk. (2020). Mengembangkan Keterampilan Berpikir Tingkat Tinggi. Jakarta: PT Kanisius.

Mawardi. (2019). Desain Penelitian

Tindakan Kelas. Yogyakarta:

Samudra Biru 
Mulyati. (2017). Terampil Berbahasa Indonesia Untuk Pergutuan Tinggi. Jakarta: Kencana.

Nurlaela, Luthfiyah, dkk. (2019). Strategi Belajar Berpikir Kreatif. Jakarta: PT Media Guru Digital Indonesia.

Ramadhani, Dini., \& Nuryanis. (2017). Analisis Kemampuan Berpikir Kreatif Matematis Siswa SD Dalam Menyelesaikan Open - Ended Problem. Jurnal JPSD ISSN: 2356-3869, Vol 4 No 2.

Rhosalia, Anggi, lulu, dkk. (2016). Kemampuan Berpikir Kreatif Dalam Menulis Naratif Siswa Kelas V Sekolah Dasar Negeri Di Kecamatan Gayungan Surabaya. Jurnal Kajian Pendidikan Dan Hasil Penelitian. ISSN: 2460-8475, Vol 2 No 2.

Sari, Ovias. (2020). Analisis Kemampuan Berpikir Kreatif Dalam Teks Cerita Pendek Karya Siswa Kelas V Sekolah Dasar. Skripsi. Bandung: Universitas Pendidikan Indonesia.

Setiawan, Iwan. (2016). Agribisnis Kreatif. Jakarta: Penebar Swadaya.

Siddik, Mohammad. (2016). Dasar-Dasar Menulis Dengan Penerapannya. Malang: Tunggal Mandiri Publishing.

Silalahi, Marito, Taruli, dkk. (2020). Peran Emosi Dalam Membangun Keterampilan Berpikir Kreatif Anak Usia Dini. Klaten: Lakeisha.

Sugiyono. (2019). Metode Penelitian Pendidikan. Bandung: Alfabeta. 